Radosław Kuliniak

Uniwersytet Wrocławski, Wrocław

ORCID: 0000-0002-0090-6609

e-mail: kornik90@poczta.onet.pl

Mariusz Pandura

Uniwersytet Wrocławski, Wrocław

ORCID: 0000-0001-5875-2705

e-mail: mariusz.pandura@uni.wroc.pl

\title{
Powojenne sprawy personalne Romana Witolda Ingardena
}

Roman Witold Ingarden swoim życiem i działalnością naukową zapisał się złotymi zgłoskami w historii lwowskiej szkoły filozoficznej ${ }^{1}$. Nie trzeba chyba nikomu przypominać, że od wczesnych lat studenckich łączyły go ścisłe stosunki z Kazimierzem Twardowskim i jego uczniami. Jeszcze przed wybuchem II wojny światowej Ingarden zasłynął we Lwowie tym, że zyskał uznanie uczniów Twardowskiego podczas ich zjazdu z okazji pierwszej rocznicy śmierci Mistrza i został wybrany na przewodniczącego Komitetu Wydawania Dzieł Twardowskiego². W 1939 roku przy-

${ }^{1}$ Rozważania zawarte we wprowadzeniu do tekstów źródłowych pokrywają się z tym, o czym pisaliśmy w pracy Filozofia po ciemnej stronie mocy. Krucjaty marksistów i komunistów polskich przeciwko Lwowskiej Szkole Filozoficznej Kazimierza Twardowskiego. Część II: Problem reformy szkolnictwa wyższego w świetle partyjnej ofensywy ideologicznej (Wydawnictwo Marek Derewiecki: Kęty, 2019), 200-231.

2 Podkreślając tym samym ważność i konieczność upowszechnienia tych treści. Zob. „Ku uczczeniu pamięci Kazimierza Twardowskiego”, Ruch Filozoficzny 1-3 (1938), T. XIV, 40-45. Zob. „W pierwszą rocznicę zgonu Kazimierza Twardowskiego”, Ruch Filozoficzny 1-2 (1939), t. 15, 5-8. 
gotował nawet w trzech czwartych trzeci numer czasopisma Studia Philosophica, poświęcony pamięci lwowskiego Profesora. Numer ten jednak w czasie wojny zaginął ${ }^{3}$. Rozwijał też Ingarden jeszcze we Lwowie inne agendy wydawnicze wraz z Twardowskim i jego uczniami. Przyczynił się między innymi do wydawania przeznaczonych dla licealistów dzieł światowych w ramach „Biblioteczki Filozoficznej”4.

Jeszcze $w$ trakcie okupacji niemieckiej Ingarden wraz z żoną przeniósł się ze Lwowa do podkrakowskiej Pieskowej Skały, gdzie jego żona podczas wojny opiekowała się gromadką dzieci, głównie uciekinierów z rzezi wołyńskiej. Stamtąd na początku 1945 roku próbował go ściągnąć do Krakowa na Uniwersytet Jagielloński dziekan Wydziału Humanistycznego, kolega z lat lwowskiej działalności, zaprzyjaźniony z nim Zygmunt Zawirski. Ingarden zaczął pełnić obowiązki służbowe na Uniwersytecie Jagiellońskim 1 lutego 1945 roku$^{5}$, kilka dni po zajęciu Krakowa przez Armię Czerwoną. Szanse na rozwój kariery zawodowej były wówczas duże. Ingarden postanowił wykorzystać je od razu, zwłaszcza że dziekan Zawirski obiecał mu nominację na profesora zwyczajnego. Sprawa stanęła na Radzie Wydziału Humanistycznego 15 maja $1945 \mathrm{roku}^{6}$, a następnie 17 maja 1945 roku została przekazana Senatowi Akademickiemu Uniwersytetu Jagiellońskiego i Ministerstwu Oświaty w Warszawie. Dziekan Zawirski uzasadnił wniosek stosownym pismem, zatytułowanym: „Sprawa mianowania Prof. Romana Ingardena profesorem zwyczajnym UJ na katedrze filozofii ścisłej". Wystąpienie i starania dziekana Zawirskiego należy uznać za ukłon w stronę osiągnięć Ingardena. To, co przedstawił w swoim wystąpieniu, poruszyło Radę Wydziału Humanistycznego i Senat Uniwersytetu Jagiellońskiego. Akceptacja dla wniosku dziekana Zawirskiego była pełna. Wydawało się też, że jest to właściwy moment, aby pomyślnie rozstrzygnąć tę

3 Zob. "Wstęp" do Korespondencji Romana Witolda Ingardena. Z dziejów "Studia Philosophica. Commentarii Societatis Philosophicae Polonorum", listy przeczytali, przepisali oraz wstępem poprzedzili Radosław Kuliniak, Dorota Leszczyna, Mariusz Pandura, Łukasz Ratajczak (Kęty: Wydawnictwo Marek Derewiecki, 2018), 7-165.

4 Zob. Protokół ze 173 posiedzenia Wydziału Polskiego Towarzystwa Filozoficznego we Lwowie, „Księga protokołów Polskiego Towarzystwa Filozoficznego we Lwowie od dn. 12 lutego 1930 roku", zawiera: Protokoły od 170 Posiedzenia Wydziału od dn. 9 V 1930 roku do Protokołu 198 Posiedzenia Wydziału z dn. 30 VI 1939 roku, w: Archiwum Ośrodka Lwowskiego w zbiorach Połaczonych Bibliotek WFiS UW, IFiS PAN i PTF. Przyczynek do inwentarza, oprac. Łukasz Ratajczak, Rkp. 2 PAN.

5 Zob. "Akta Osobowe - Roman Witold Ingarden (1893-1970)”, "Archiwum Uniwersytetu Jagiellońskiego", S III 246 (Legitymacja tymczasowa Nr 380 Romana Ingardena, wydana przez prorektora Uniwersytetu Jagiellońskiego Tadeusza Dziurzyńskiego 1 lutego 1945 roku).

6 Zob. „Akta Prof. Roman Ingarden”, ,Archiwum Uniwersytetu Jagiellońskiego", WHm 41 (Wypis z posiedzenia Rady Wydziału Filozoficznego UJ w dniu 15 maja $1945 \mathrm{roku})$. 
kwestię. Kraków sprawiał wówczas wrażenie bastionu starej, przedwojennej profesury i przynajmniej początkowo, pomimo swojego konserwatywnego nastawienia, był miastem o pozytywnym nastawieniu do przybyszów ze Lwowa i z Wilna. Później dopiero miało się okazać, że "lwowskiej inwazji" krakusi jednak nie byli przychylni. Nazywali swoich kolegów profesorów ze Lwowa „profesorami zagranicznymi”.

Dziekan Zawirski miał nadzieję, że sprawa Ingardena zostanie szybko i pomyślnie załatwiona w Ministerstwie Oświaty. Niespodziewanie jednak pojawiły się pewne przeszkody. W kwestii nominacji Ingardena na profesora zwyczajnego, popieranej przez dziekana Zawirskiego, a także Radę Wydziału Humanistycznego oraz Senat Uniwersytetu Jagiellońskiego, zaczął działać przeciwny ich działaniom czynnik partyjny, już wówczas sceptycznie nastawiony do starej, przedwojennej profesury. Zaczęto bacznie przyglądać się Ingardenowi. Oczywiście jawnie nie zaprotestowano wobec jego przyjęcia i nominacji, lecz podjęto kroki mające spowolnić cały ten proces.

Entuzjastyczne nastawienie dziekana Zawirskiego okazało się dla Ingardena przedwczesne. Już podczas swoich pierwszych krakowskich starań natrafił on na opór, który trwał w nieskończoność, kolejne przeszkody się mnożyły, a sytuacja nie uległa poprawie aż do jego przejścia na emeryturę. Władze uniwersyteckie, a dokładnie zmieniający się niemalże nieustannie przedstawiciele szybko zainstalowanej komórki partyjnej PPR-u przy Uniwersytecie Jagiellońskim, nieustannie próbowały kwestionować osiągnięcia i sukcesywnie utrudniać awans Ingardena. $\mathrm{Na}$ pierwszy plan wysunęła się kwestia potwierdzenia autentyczności jego dyplomu doktorskiego. Sprawa ta krążyła między rektoratem, dziekanatem a Ministerstwem Oświaty przez wiele kolejnych, długich lat. Choć Ingarden posiadał kilka odpisów swojego dyplomu, to żaden z nich nie został uznany - zarówno ten wydany przez władze Uniwersytetu we Fryburgu, jak i ten wydany przez władze Uniwersytetu we Lwowie, gdzie takie potwierdzenie się znajdowało, lecz pomimo licznych starań nie można było go stamtąd wydobyć. Dopiero niedawno, podczas jednej z kwerend lwowskich, udało nam się ten dokument pozyskać. Widnieje na nim zapis o nostryfikacji, konieczny przy ubieganiu się przez Ingardena o kolejne stopnie naukowe i stanowiska. Czytamy tam:

Nr 164/1931, 6 marca 1931

Stwierdzam dosłowną zgodność powyższego tekstu z tekstem przedłożonego mi oryginalnego dyplomu, wydanego przez Uniwersytet Fryburski w Breisgau i opatrzonego pieczęcią Kancelarii tegoż Uniwersytetu. Ponadto stwierdzam, że dyplom oryginalny ma na odwrocie klauzulę łacińską Uniwersytetu Jana Kazimierza z datą 5 czerwca 1924, uznającą dyplom ten za równoważny z dyplomem doktora filozofii Uniwersytetu 
Jana Kazimierza. [Podpisał:] Dr Podlacha, Dziekan Wydziału Humanistycznego U.J.K. ${ }^{7}$

Gdyby Ingarden posiadał wówczas potwierdzony dyplom doktorski, nie byłoby problemów z jego nostryfikacją. W zaistniałych okolicznościach problem jednak powracał, a sprawie nieustannie przyglądali się działacze partyjni zmuszający władze rektorskie i ministerialne do przeprowadzania kontroli. Za każdym razem uznawano, że kwestia dyplomu doktorskiego to niepewny punkt w karierze naukowej filozofa, co przez pewien czas było dla Ingardena ogromnym ciężarem. Filozof wystarał się nawet o trzy "Odpisy z odpisu”, które niestety w żaden sposób nie wpłynęły na polepszenie sytuacji. Dopiero w 1953 roku, a dokładnie 21 grudnia, Centralna Komisja Kwalifikacyjna dla Pracowników Nauki wydała w tej sprawie ostateczne zaświadczenie. Dziwna to sprawa. Pomimo braku ponownej nostryfikacji doktoratu Ingarden zaczął pracować na Uniwersytecie Jagiellońskim nie jako mianowany profesor, lecz jako profesor kontraktowy, zatrudniony od 1 grudnia 1945 roku do 31 sierpnia 1946 roku$^{8}$; następnie zaproponowano mu kontrakt na okres od 1 września 1946 roku do 31 września 1947 roku9 . Jednocześnie otrzymał zapewnienie od rektora Uniwersytetu Jagiellońskiego, że jego sprawy są w toku i należy poczekać kilka miesięcy, zanim zostaną rozstrzygnięte.

Co ciekawe, w takich okolicznościach Ingarden zdecydował się dość odważnie przedstawić warunki swojego zatrudnienia. W liście do dziekana Wydziału Humanistycznego z 12 grudnia 1945 roku pisał:

Wielce Szanowny Panie Dziekanie!

W myśl propozycji Jaśnie Wielmożnego Pana Dziekana gotów jestem zawrzeć z Uniwersytetem Jagiellońskim kontrakt na bieżący rok akademicki, z tym jednak, że następujące sprawy zostaną wyjaśnione, resp. ustalone:

7 Dyplom doktorski (kopia) Romana Witolda Ingardena, potwierdzony przez Władysława Podlachę, dziekana Wydziału Humanistycznego UJK 6 marca 1931 roku, Archiwum Lwowskiego Narodowego Uniwersytetu imienia Iwana Franki, оп. 1, ед. хр. 73: Аичное дело профессора немецкой литературы Ингардена Романа Романовича, k. $10 \mathrm{r}$.

8 Zob. „Akta Osobowe - Roman Witold Ingarden (1893-1970)”, ",Archiwum Uniwersytetu Jagiellońskiego", S III 246 (Odpis z 12 kwietnia 1946 r. umowy o pracę zawartej między rektorem Uniwersytetu Jagiellońskiego Tadeuszem Lehrem-Spławińskim a Romanem Witoldem Ingardenem w Krakowie 1 grudnia 1945 roku).

9 Zob. „Akta Osobowe - Roman Witold Ingarden (1893-1970)”, ,Archiwum Uniwersytetu Jagiellońskiego", S III 246 (Niepodpisana przez rektora umowa o pracę między rektorem Uniwersytetu Jagiellońskiego a Romanem Witoldem Ingardenem z 15 lipca 1946 roku). 
1) Że wobec utworzenia II Katedry Filozofii na Wydziale Humanistycznym UJ zostanie utworzony odrębny Oddział Seminarium Filozoficznego z osobnym budżetem i osobnym asystentem, organizacyjnie związany $\mathrm{z}$ innymi oddziałami tegoż Seminarium, przy czym ewentualnie Seminarium to zostanie przekształcone na Zakład Filozoficzny (ewentualnie wspólny dla obu Wydziałów, o ile to jest organizacyjnie możliwe).

2) Ze zostanie mi powierzone kierownictwo jednego z Oddziałów Seminarium, resp. Zakładu Filozoficznego, i przydzielony mi zostanie osobny, przeze mnie zaproponowany asystent.

3) Że dotacja tworzonego obecnie oddziału Seminarium Filozoficznego nie będzie mniejsza od dotacji któregokolwiek z pozostałych oddziałów tegoż Seminarium (w szczególności oddziału związanego z Wydziałem Matema.-Przyrodniczym). O ile mi wiadomo, w tej chwili dotacja Seminarium Filozoficznego na Wydziale Mat.-Przyrodniczym jest kilka razy wyższa od dotacji na Wydziale Humanistycznym. Wydaje się to nieuzasadnione wobec faktu, że biblioteka Seminarium Filozoficznego jest w znacznej mierze przestarzała i wykazuje liczne braki zwłaszcza w dziedzinie metodologii nauk humanistycznych i tych działów filozofii, które są związane z zagadnieniami humanistycznymi (etyka, estetyka, filozofia języka, filozofia historii, filozoficzna socjologia itd.). Prócz tego ilość nowszych książek angielskich, francuskich i amerykańskich jest znikoma, a to samo odnosi się do czasopism zagranicznych. Brak wreszcie krytycznych wydań wielu klasyków filozofii, zwłaszcza Anglików i Francuzów. Wskutek tego biblioteka ta wymaga przez szereg lat znaczniejszych wkładów, żeby można ją było doprowadzić do poziomu sprawnego narzędzia pracy naukowej.

4) Że zostanie powiększony obecny lokal Seminarium Filozoficznego, który na potrzeby trzech katedr filozofii jest zbyt szczupły. Czy dokona się to przez przydzielenie nowego lokalu, czy też przez ponowny podział lokali znajdujących się w domu przy u. Piłsudzkiego 13, to nie odgrywa większej roli.

5) Że zostanie wyjaśniona sprawa przydziału egzaminów magisterskich dla niżej podpisanego przez zawarcie odpowiedniej umowy, co dotyczy to rozdziału poszczególnych typów egzaminów na poszczególnych profesorów, czy też przez przyjęcie zasady, że kandydat ma prawo wyboru egzaminatora ${ }^{10}$.

Oczywiście nie wszystkie te warunki zostały spełnione. Na razie, aby uspokoić Ingardena, przyznano mu prawo bycia egzaminatorem przy egzaminach magisterskich, a także przyjęto go z datą 4 października 1945 roku w poczet czynnych członków Rady Wydziału Humanistycznego Uniwersytetu Jagiellońskiego ${ }^{11}$. Później sukcesywnie rektor

10 Zob. „Akta Osobowe - Roman Witold Ingarden (1893-1970)”, „Archiwum Uniwersytetu Jagiellońskiego", S III 246 (List Ingardena do dziekana Wydziału Humanistycznego o warunkach zatrudnienia).

11 Zob. "Akta Osobowe - Roman Witold Ingarden (1893-1970)”, „Archiwum Uniwersytetu Jagiellońskiego", S III 246 (Pismo Rady Wydziału Humanistycznego o przyjęciu Ingardena w poczet swoich członków). 
i dziekan ulegali Ingardenowi, lecz nie udało się sprostać jego oczekiwaniom w kwestii poszerzenia budżetu; ostatecznie rozbudowanie biblioteki filozof wziął po części na siebie. Przydzielono mu także seminarium filozoficzne i pozwolono objąć Zakład Filozofii na Wydziale Matematyczno-Przyrodniczym, gdzie otrzymał również własne seminarium.

Kolejnym krokiem w powojennej karierze Ingardena na Uniwersytecie Jagiellońskim było potwierdzenie jego nominacji na stanowisko profesora w II Katedrze Filozofii. Nadeszło ono z Ministerstwa Oświaty NrIP-3174/46 do Rektoratu Uniwersytetu Jagiellońskiego dopiero 20 lutego 1946 roku. W piśmie tym zapisano:

Odpowiedź na pismo z dnia 20 XII 1945 r. Nr 5775/45

Ministerstwo Oświaty wyraża zgodę na powierzenie ob. Prof. Romanowi Ingarden na okres czasu od dnia 1 grudnia 1945 roku do dnia 31 sierpnia 1946 roku pełnienia obowiązków profesora na II Katedrze Filozofii na podstawie umowy $\mathrm{z}$ wynagrodzeniem odpowiadającym grupie IV (czwartej) zasadniczego uposażenia funkcjonariuszów państwowych wraz z przynależnymi tej grupie wszelkimi dodatkami tudzież dodatkiem wojennym i naukowym ${ }^{12}$.

W tym okresie Ingarden prowadził działalność naukowa jednak nadal martwił się o utratę stanowiska i spotykały go różne niespodzianki. Zaczęły się one pojawiać wraz z podjęciem pracy nad wznowieniem i wydaniem trzeciego numeru czasopisma Studia Philosophica. Ingarden został wówczas obarczony stertą materiałów administracyjno-budżetowych i musiał sam, zwykle bez pomocy współredaktora pisma Ajdukiewicza, zmagać się z urzędnikami uniwersyteckimi i ministerialnymi. Do tego dochodziły często trudne rozmowy z różnymi wydawnictwami, już wówczas pozostającymi na garnuszku partii. Dzięki staraniom Ingardena po wielu trudach doszło do wydania trzeciego tomu pisma, poświęconego pamięci Kazimierza Twardowskiego oraz innych zmarłych i pomordowanych w czasie wojny filozofów ${ }^{13}$. Długie lata kłuł on później w oczy Adama Schaffa i jego marksistowskie przedszkole. Angażował się też Ingarden w prace nad odnową ruchu filozoficznego w Polsce. Był uczestnikiem słynnej konferencji filozoficznej w Zakopanem. Pracował i przejął opiekę redaktorską nad wydawaniem przekładów dzieł światowych filozofów oraz Kwartalnika Filozoficznego. Wszystkim tym pracom towarzyszyły jednak, jak zaznaczyliśmy, liczne niespodzianki.

${ }^{12}$ Zob. „Akta Osobowe - Roman Witold Ingarden (1893-1970)”, „Archiwum Uniwersytetu Jagiellońskiego", S III 246 (Nominacja Ingardena na II Katedrę Filozofii w Uniwersytecie Jagiellońskim).

${ }^{13}$ Zob. Studia Philosophica. Commentarii Societatis Philosophicae Polonorum, vol. 3, 1939-1946, wyd. 1948: "In memoriam philosophorum Polonorum qui inde ab A. D. MCMXXXVIII mortui sunt". 
Najtrudniejsze do zaakceptowania przez Ingardena były te wynikające z jawnej inwigilacji, jakiej podlegał od czasu zakończenia wojny. Ingarden okazał się przedwojennym filozofem, który był nieustannie obserwowany podczas swej pracy uniwersyteckiej. Nikogo z filozofów tak nie prześwietlano. 28 października 1946 roku zmuszono go po raz pierwszy do złożenia odpowiedniej „Deklaracji”. Brzmiała ona:

Deklaracja

Ja niżej podpisany Roman Witold Ingarden jestem narodowości polskiej. Tak samo narodowości polskiej jest moja żona Dr Maria z domu Pol. Żona moja jest obecnie kontraktową lekarką szkolną w państwowych szkołach średnich w Krakowie, praktyki prywatnej nie prowadzi. Znam języki: łaciński, grecki, niemiecki, francuski i angielski. Znam: Niemcy, Francję, Austrię, Czechy, Szwajcarię ${ }^{14}$.

Dodajmy, że Ingarden jeszcze w styczniu 1946 roku, asekurując się nieco i martwiąc o dalsze zatrudnienie, podjął wykłady z estetyki w Wytwórni Filmowej Wojska Polskiego i na Studium Spółdzielczym Wydziału Rolniczego Uniwersytetu Jagiellońskiego. Uzyskał poparcie w tym względzie od rodzimej Rady Wydziału Humanistycznego, która zwróciła się ze stosownym pismem do Ministerstwa Oświaty. Sprawa ta - dodajmy - została po jakimś czasie zaakceptowana ${ }^{15}$.

Dość powiedzieć, że kolejne dokumenty Ingarden musiał złożyć we wrześniu 1947 roku. Gromadząc materiały uzupełniające historię jego życia i pracy naukowej, pochodzące głównie ze Lwowa i potwierdzane notarialnie w Krakowie, wykazywał się nie lada cierpliwością. Chyba nie było wówczas drugiego takiego przedwojennego filozofa, który podlegałby tak wnikliwej inwigilacji. Na początku wspomnianego roku akademickiego 1947/1948 Ingarden nieoczekiwanie dostał pismo o potrzebie pilnego dostarczenia w możliwie jak najkrótszym terminie dowodów swojej pracy z lat 1918-1933 ${ }^{16}$. Konieczne ponadto było przedłożenie metryk urodzenia i innych odpisów z akt metrykalnych, dotyczących

14 Zob. "Akta Osobowe - Roman Witold Ingarden (1893-1970)”, „Archiwum Uniwersytetu Jagiellońskiego", S III 246 (Deklaracja osobowa Ingardena o sobie i rodzinie). Ingarden nieco później musiał ponowić swoją „Deklarację”, rozpisując ją na osobne części, dotyczące jego, żony, znajomości języków i świata.

15 Zob. „Akta Osobowe - Roman Witold Ingarden (1893-1970)”, „Archiwum Uniwersytetu Jagiellońskiego", S III 246 (Pismo wspierające Rady Wydziału i zatwierdzenie nominacji Ingardena z Ministerstwa Oświaty).

16 Zob. „Akta Osobowe - Roman Witold Ingarden (1893-1970)”, „Archiwum Uniwersytetu Jagiellońskiego", S III 246 (Dokumenty dotyczą okresu pracy w Lublinie, Warszawie, Toruniu i Lwowie w okresie przedwojennym). 
dzieci i małżonki ${ }^{17}$. Ponownie wyrażano w tym czasie wątpliwości co do narodowości obojga małżonków. Pytano znów o znajomość języków, znajomość krajów, w których filozof bywał przed wojną, a także o przebieg pracy zawodowej jego żony. Przyszło też z rektoratu ponaglenie dotyczące konieczności złożenia dokumentów w sprawie przeniesienia Ingardena przed wojną do V Gimnazjum Państwowego we Lwowie ${ }^{18}$. Oczywiście Ingarden starał się w miarę możliwości dostarczać wymagane pisma.

Następna nominacja, ta właściwa i długo oczekiwana, zwłaszcza przez dziekana Zawirskiego, została podjęta 12 czerwca 1946 roku. Ingarden został wówczas profesorem zwyczajnym Uniwersytetu Jagiellońskiego. Wiązało się to z przydziałem służbowym i dydaktycznym. Według obowiązujących zasad filozof dostał w przydziale piastowaną już II Katedrę Filozofii na Wydziale Humanistycznym, Seminarium Filozoficzne wraz z opieką nad Zakładem Filozoficznym na Wydziale Matematyczno-Przyrodniczym oraz pięć godzin wykładów i dwie godziny ćwiczeń tygodniowo w ciągu całego roku akademickiego. Potwierdzenie tego mianowania spłynęło do rektoratu 17 lipca 1946 roku. W stosownym piśmie podpisanym przez dyrektora Departamentu w Ministerstwie Oświaty Emila Kuroczko zapisano:

\begin{abstract}
Odpowiedź na pismo z dnia 8 X 1945 r. Nr 3957/45
Ministerstwo Oświaty przesyła w załączeniu dekret Prezydenta Krajowej Rady Narodowej z dnia 12 czerwca 1946 r. mianujący ob. Prof. dra Romana Ingardena profesorem zwyczajnym Filozofii II na Wydziale Humanistycznym Uniwersytetu Jagiellońskiego oraz pismo określające wymiar godzin nauczania, celem zarządzenia doręczenia zainteresowanemu $\mathrm{z}$ dowodem odbioru, odnotowania na dekrecie i w aktach personalnych daty objęcia obowiązków asygnowania uposażenia służbowego i wydania dalszych koniecznych zarządzeńn ${ }^{19}$.
\end{abstract}

Nominacja ta uspokoiła Ingardena. Sprawiła, że rzucił się w wir pracy dydaktycznej i naukowej. Gros czasu zajmowało mu przygotowanie trzeciego numeru czasopisma Studia Philosophica. Pracował również w Kwartalniku Filozoficznym, a także na rzecz scalenia powojennego ruchu filozoficznego w Polsce. Lata jednak mijały, a władze partyjne

17 Zob. "Akta Osobowe - Roman Witold Ingarden (1893-1970)”, „Archiwum Uniwersytetu Jagiellońskiego", S III 246 (Ingarden z trudem zyskał te dokumenty i z potwierdzeniem notarialnym złożył ostatecznie w UJ).

18 Zob. ,Akta Osobowe - Roman Witold Ingarden (1893-1970)”, , ,Archiwum Uniwersytetu Jagiellońskiego", S III 246 (Rektorat uznał, że Ingarden jest zbyt opieszały w gromadzeniu i przedłożeniu stosownych dokumentów i w 1947 wysłał do niego stosowne ponaglenie).

19 Zob. ,Akta Osobowe - Roman Witold Ingarden (1893-1970)", ,A Archiwum Uniwersytetu Jagiellońskiego", S III 246 (Nominacja Ingardena na profesurę zwyczajną). 
i ministerialne rozwijały swoją ofensywę ideologiczną. Czuć było coraz większą presję wywieraną na środowiska akademickie. Uniwersytet Jagielloński wraz z Polską Akademią Umiejętności, w której działał także Ingarden, stał się ostatnim bastionem oporu i opozycji wobec propozycji marksistów oraz komunistycznych agitatorów partyjnych. Ingarden przyjął od samego początku twardą zasadę niemieszania się $\mathrm{w}$ spory polityczno-partyjne. Nie uczestniczył w niemal żadnych spotkaniach ideologicznych narzuconych przedstawicielom kadry profesorskiej. Z rzadka wypowiadał się w jakikolwiek sposób o marksizmie w ogóle. Przyjął zasadę nierozmawiania z marksistami, a jeżeli już do tego miało dojść, to traktował to jako konieczność formalną. Obserwował jednak czujnie, jakby z boku, co wokół niego się działo. Władze uniwersyteckie pozostające pod presją partyjna, szukając na Ingardena przez pierwsze niemal pięć lat jego pracy haków, nie znalazły ich niemal wcale. Oczywiście w działaniach Ingardena zdarzały się pewne niefrasobliwości, jak chociażby jego wystąpienia proszone na zjazdach polonistów czy też nawiązywanie nowych i podtrzymywanie starych, wypróbowanych kontaktów zagranicznych, lecz były to zdarzenia incydentalne, do których nawet partyjni agitatorzy nie mogli się przyczepić. Ingarden przywiązywał ogromną wagę do swojego zachowania w relacjach $\mathrm{z}$ marksistami. Często unikał z nimi jakichkolwiek kontaktów. Dbał o rodzinę i wytrwale pracował na niwie uniwersyteckiej. Tak było do czasu uchwalenia i wprowadzenia zasad znoszących eklektyzm filozofii wykładanej na uniwersytetach. Rozporządzenie z 1948 roku wymuszało redukcję zajęć z filozofii do historii filozofii, logiki i materializmu dialektycznego. Pierwszymi ofiarami tego rozporządzenia stali się: Władysław Tatarkiewicz, Maria i Stanisław Ossowscy, a także Henryk Elzenberg. Wezwania na dywanik ministerialny do Krassowskiej oczekiwał również Ingarden.

Zanim to jednak nastąpiło, jesienią 1949 roku Ingarden rozchorował się i z żalem musiał zrezygnować z części obowiązków. W 1948 roku, po śmierci prof. Zawirskiego, przejął jego obowiązki i prowadził przez niemal dwa lata jego Seminarium Filozoficzne II i inne zajęcia w II Katedrze Filozofii na Wydziale Matematyczno-Przyrodniczym. Długi czas jednak nie odbywał zajęć. Zaniepokojony tym faktem dziekan Wydziału Matematyczno-Przyrodniczego Uniwersytetu Jagiellońskiego, prof. Bogdan Kamieński, 3 kwietnia 1950 roku przez Rektorat Uniwersytetu Jagiellońskiego zwrócił się z pismem do Ministerstwa Oświaty z prośbą o przejęcie wykładów zleconych Ingardena, czyli „Głównych zasad filozofii”, i przekazanie ich dr. Witoldowi Galeńskiemu, starszemu asystentowi przy II Seminarium Filozoficznym. W tej sprawie Ingarden nie protestował. Inaczej było z jego rezygnacją z prowadzenia II Seminarium Filozoficznego na Wydziale Matematyczno-Przyrodniczym po Zawirskim. 28 czerwca 1950 roku skierował pismo do Rady Wydziału Matematyczno-Przyrodniczego Uniwersytetu Jagiellońskiego. Pisał w nim: 
Proszę uprzejmie o zwolnienie mnie z dn. 1 września br. z kierownictwa Seminarium Filozoficznego II. Pełnienia kierownictwa tego Zakładu podjąłem się przed przeszło dwu laty, spodziewając się, że Katedra Filozofii na Wydziale Mat-Przyr. zostanie rychło obsadzona. Tymczasem mimo przeszło dwu lat i mimo uchwały Rady Wydziału Mat.-Przyr. z grudnia r. 1949, powołującej prof. J. Słupeckiego na profesora filozofii na Wydziale Mat.-Przyr. UJ, sprawa ta dotychczas nie wkroczyła na realne tory (wniosek Rady Wydziału nie został wysłany do Ministerstwa Oświaty, resp. Nauki i Szkół Wyższych, i nie wiadomo, kiedy to się stanie). Nie ma tedy nadziei, że z początkiem r. ak. 1950/51 rozpocznie się normalne funkcjonowanie Katedry i Zakładu Filozofii na Wydziale Mat.-Przyr. Nie mogąc prowadzić prac dydaktycznych i badawczych dwu katedr, resp. spraw administracyjnych dwu zakładów równocześnie, przez czas dłuższy nie mogę w wyłuszczonym wyżej stanie rzeczy przyjąć odpowiedzialności za stan spraw filozofii na Wydziale Mat.-Przyr. UJ. Nie mogę przyjąć tej odpowiedzialności także z tego względu, że - jak doszły mnie pośrednio wiadomości - występuje na wydziale tendencja do zamiany Katedry Filozofii na Katedrę Logiki, co nawet doprowadziło do pewnych faktów, zaszłych bez porozumienia się ze mna, a niezgodnych z istniejącymi uchwałami Rady Wydziału Mat.-Przyr. Muszę wreszcie podkreślić, że pełnienie przez czas dłuższy (notabene zupełnie bezpłatnie) dodatkowych obowiązków, polegających na prowadzeniu drugiego zakładu, prowadzi do zbytniego przeciążenia mnie i odbija się ujemnie na stanie mego zdrowia i stanie mych prac naukowych. Będę tedy bardzo wdzięczny Radzie Wydziału Mat.-Przyr. za łaskawe zwolnienie mnie z pełnienia kierownictwa Zakładu Filozofii i za mianowanie nowego jego kierownika do czasu objęcia katedry przez prof. J. Słupeckiego ${ }^{20}$.

W tej sytuacji dziekanowi Wydziału Matematyczno-Przyrodniczego nie pozostało nic innego, jak przyjąć rezygnację Ingardena i poszukać jego następcy. Zwrócił się on do prof. Władysława Heinricha, Kierownika I Seminarium Filozoficznego, i 4 lipca 1950 roku poprosił o przejęcie opieki nad II Seminarium Filozoficznym, które po śmierci Zawirskiego od 1948 roku prowadził Ingarden. W piśmie tym zapisano:

Na podstawie uchwały Rady Wydziału Mat.-Przyrodniczego Uniwersytetu Jagiellońskiego z 30 marca 1950 roku zwracam się do Pana Profesora z najuprzejmiejszą prośbą o przejęcie opieki nad II Seminarium Filozoficznym UJ, osieroconym od dłuższego czasu wskutek śmierci śp. prof. dra Zygmunta Zawirskiego. Tymczasowym kierownikiem tego zakładu był dotychczas prof. dr Roman Ingarden, który jednak z powodu złego stanu zdrowia zrezygnował z tego stanowiska. Wybrany przez Radę

${ }^{20}$ Zob. "Akta Osobowe - Roman Witold Ingarden (1893-1970)”, „Archiwum Uniwersytetu Jagiellońskiego", S III, 246 (Pismo służbowe Ingardena do dziekana Wydziału Matematyczno-Przyrodniczego Uniwersytetu Jagiellońskiego w sprawie rezygnacji z zajęć i funkcji służbowych). 
Wydziału Mat.-Przyrodniczego na II Katedrę Filozofii UJ prof. dr Jerzy Słupecki dotychczas nie wyraził definitywnej zgody na objęcie katedry wobec braku mieszkania w Krakowie ${ }^{21}$.

Jeszcze w tym samym dniu dziekan, prof. Bogdan Kamieński, napisał list do Ingardena ${ }^{22}$. Uznał, że wypada mu podziękować za zaangażowanie i bezinteresowne prowadzenie zajęć i wskazanej katedry. Zdecydował się na wysłanie takiego pisma, ponieważ żywił nadzieję, że zakończy ono współpracę z Ingardenem i nie spowoduje dalszych nieporozumień. Tak jednak się nie stało. Ingarden odpowiedział na list dziekana Kamieńskiego 5 lipca 1950. Pisał w nim:

Z pisma Pana Dziekana Wydziału Humanistycznego UJ [błąd; winno być: Wydziału Matematyczno-Przyrodniczego] do prof. Heinricha, jako kierownika Zespołu Katedr Filozoficznych UJ, pisma udzielonego mi do wiadomości przez prof. Heinricha, dowiedziałem się, że Katedra Filozofii na Wydziale Matematyczno-Przyrodniczym ma być przemianowana na Katedrę Logiki i przydzielona wedle uchwały Rady Wydziału Matematyczno-Przyrodniczego do Instytutu Matematycznego UJ, nie ma więc należeć do Zespołu Katedr Filozoficznych UJ.

W związku z tym ośmielam się zwrócić do Wielce Szanownego Pana Dziekana z uprzejmym zapytaniem, czy istotnie tego rodzaju uchwała Rady Wydziału Matematyczno-Przyrodniczego zapadła i kiedy się to $\mathrm{w}$ danym razie stało. Nic mi bowiem o takiej uchwale nie wiadomo. Wątpię również, by mogła się ona była dokonać bez porozumienia się ze mną jako z tymczasowym kierownikiem Katedry Filozofii i jako członkiem Komisji Filozoficznej do obsady tej katedry wybranej. Sprawa zmiany nazwy i zakresu katedry musiałaby wpierw znaleźć się na posiedzeniu tej komisji, która nie była zwołana od czasu posiedzenia, na którym uchwalono zaprosić na Katedrę Filozofii p. prof. Słupeckiego. Pan prof. Słupecki też przyjął Katedrę Filozofii i nic mi nie wiadomo, jakoby co do zakresu tej katedry zgłosił jakieś zastrzeżenia.

Być może, że odnośna uchwała zapadła na przedostatnim posiedzeniu Rady Wydziału Matematyczno-Przyrodniczego, na którego początku byłem obecny, ale które - po porozumieniu się z Wielmożnym Panem Dziekanem - musiałem opuścić, gdyż równocześnie odbywało się posiedzenie Rady Wydziału Humanistycznego. Ale i to przypuszczenie wydaje mi się mało prawdopodobne, albowiem Rada Wydziału Matematyczno-Przyrodniczego przy ewentualnym wyłonieniu się sprawy przemianowania katedry byłaby była niezawodnie wstrzymała się z decyzją

${ }^{21}$ Zob. „Akta Osobowe - Roman Witold Ingarden (1893-1970)”, „Archiwum Uniwersytetu Jagiellońskiego", S III 246 (Pismo dziekana Wydziału Matematyczno-Przyrodniczego Uniwersytetu Jagiellońskiego do prof. Heinricha w sprawie objęcia przez niego stanowiska zwolnionego po Ingardenie).

${ }^{22}$ Zob. „Roman Ingarden”, „Archiwum Uniwersytetu Jagiellońskiego”, WMP 78 (List dziekana Wydziału Matematyczno-Przyrodniczego do Ingardena z podziękowaniami za współpracę). 
aż do czasu porozumienia się ze mna, resp. aż do czasu uchwały odnośnej komisji. Przypuszcza więc, że cała informacja Pana Dziekana Wydziału Humanistycznego polega na jakimś nieporozumieniu i będę niezmiernie wdzięczny Wielce Szanownemu Panu Dziekanowi za łaskawe poinformowanie mnie o faktycznym stanie rzeczy ${ }^{23}$.

Sprawa znalazła ostatecznie swoje polubowne rozwiązanie.

Jesienią 1950 roku przyszła kolej na następne niekorzystne rozstrzygnięcia dla Ingardena. Filozof został zaproszony do Warszawy na rozmowę z wiceminister Krassowska, wykonującą polecenia partyjne. Udał się tam 13 września 1950 roku. W Ministerstwie Oświaty przyjęto go dość chłodno. Najpierw czekał przeszło trzy godziny, a gdy znudzony zamierzał opuścić już gmach ministerstwa, został zawrócony i wreszcie przyjęty. W krótkiej rozmowie wiceminister Krassowska poinformowała filozofa, że w wyniku prac rekonstrukcyjnych, wprowadzanych właśnie w życie, w obszarze filozofii następują poważne redukcje. W ich rezultacie ministerstwo postanowiło między innymi zamknąć prowadzoną przez Ingardena II Katedrę Filozofii na Uniwersytecie Jagiellońskim. Sam Ingarden, oprócz utraty własnej katedry, został przeniesiony w tzw. stan nieczynny. Do końca nie było wiadomo, co to miało oznaczać. Wiceminister Krassowska poinformowała go, że najlepiej by było, gdyby nie podejmował żadnych działań i cierpliwie oczekiwał na kolejne ustalenia, które w najbliższym czasie zostaną przekazane do rektoratu Uniwersytetu Jagiellońskiego. Otrzymana przez Ingardena decyzja, choć nie była dla niego zaskoczeniem, jako że spodziewał się takiego obrotu spraw, bardzo go rozczarowała. Podłamany niepomyślną informacją filozof szybko powrócił do Krakowa. Pierwsze dni były trudne. Powróciły stare lęki i obawy o przyszłość. Później jednak Ingarden zebrał się w sobie i powrócił do swoich zadań, głównie pracy w Kwartalniku Filozoficznym. Wieść o jego problemie szybko rozeszła się w światku filozoficznym. Ingarden oczekiwał wówczas może nie tyle wsparcia lub interwencji w swojej sprawie, lecz konsolidacji środowiska. Wiedział, że jedność i zgrupowanie wszystkich filozofów w geście protestu mogą przynieść sukces. Nic takiego jednak nie nastąpiło. W Warszawie milczał Kotarbiński, a z Poznania Ajdukiewicz też nie zamanifestował swojego sprzeciwu. Nikt nie stanął w obronie polskiej filozofii. Jedynie z Gdańska przyszły ciepłe słowa otuchy i wparcia od Dąmbskiej. Było to jednak za mało, aby ratować tonący okręt. Zbliżał się nowy rok akademicki 1950/1951. W związku z tym Ingarden postanowił dowiedzieć

${ }^{23}$ Zob. „Roman Ingarden”, „Archiwum Uniwersytetu Jagiellońskiego”, WMP 78 (List Ingardena do dziekana Wydziału Matematyczno-Przyrodniczego Uniwersytetu Jagiellońskiego w sprawie przydziału zajęć z filozofii na tym wydziale). List został błędnie datowany „5 VI 1950” (właściwa data: 5 lipca 1950 roku). 
się czegoś o planach władz wobec niego. Rektor z dziekanem jednak milczeli i unikali kontaktów z filozofem. Poirytowany tym faktem Ingarden wystosował 30 września 1950 roku pismo do dziekana Wydziału Humanistycznego. Pisał w nim:

W dniu 13 września br. p. wiceminister Krassowska w Ministerstwie Szkół Wyższych i Nauki oświadczyła mi, że Katedra Filozofii II, którą zajmuję, została zniesiona i że wobec tego zostanę z dniem 1 października br. przeniesiony na rok w stan nieczynny. Do dnia 30 IX br. nie doręczono mi żadnego pisma urzędowego w tej sprawie, a w Dziekanacie Humanistycznym UJ oświadczono mi ustnie, że żadne pismo w tej sprawie nie nadeszło dotychczas do Dziekanatu. Wobec tego, że z dniem 1 października br. rozpoczyna się nowy rok akademicki, a ja w danym razie winien byłbym rozpoczać wykłady $\mathrm{w} \mathrm{dn} .2 \mathrm{X}$ br., a nie mogę tego uczynić z powodu nieistnienia katedry, na której wykładałem, proszę uprzejmie Dziekanat Wydziału Humanistycznego o wyjaśnienie, co mam robić, ewentualnie o udzielenie mi płatnego urlopu do czasu wyjaśnienia sprawy. Proszę zarazem o podanie osoby, której miałbym przekazać kierownictwo Zakładu Filozoficznego (Oddział III), którym do dnia dzisiejszego kierowałem, tudzież o wymienienie daty, w której byłbym zobowiązany to zrobić ${ }^{24}$.

W tej sytuacji ani dziekan, ani rektor nie podjęli żadnej wiążącej decyzji. Zapanowała zmowa milczenia. Przez cały październik i jedenaście dni listopada Ingarden tkwił w absolutnym zawieszeniu i niepewności. Odbiło się to na jego zdrowiu. Wreszcie 11 listopada rektor Uniwersytetu Jagiellońskiego zaproponował, aby Ingarden udał się na urlop w celu podratowania zdrowia ${ }^{25}$. Miał jedynie zawiadomić, kiedy zamierza go rozpoczać, a w razie wyjazdu pozostawić adres do korespondencji. Pismo rektora uzupełnia $\mathrm{w}$ tym względzie pismo wiceminister Krassowskiej do rektora Uniwersytetu Jagiellońskiego. Czytamy w nim:

Udzielam ob. dr. Romanowi Ingardenowi, profesorowi zwyczajnemu filozofii na Wydziale Humanistycznym Uniwersytetu Jagiellońskiego w Krakowie, płatnego urlopu do czasu zlikwidowania zajmowanej przez niego katedry ${ }^{26}$.

${ }^{24}$ Zob.,,Akta Prof. Roman Ingarden”, ,'Archiwum Uniwersytetu Jagiellońskiego”, WHm 41 (List Ingardena do dziekana Wydziału Humanistycznego Uniwersytetu Jagiellońskiego w sprawie pracy w nowym roku akademickim).

25 Zob. „Akta Osobowe - Roman Witold Ingarden (1893-1970)”, „Archiwum Uniwersytetu Jagiellońskiego", S III, 246 (Postanowienie rektora Uniwersytetu Jagiellońskiego o urlopowaniu Ingardena do czasu likwidacji zajmowanej przez niego katedry).

${ }^{26}$ Zob. "Akta Osobowe - Roman Witold Ingarden (1893-1970)”, „Archiwum Uniwersytetu Jagiellońskiego", S III 246 (Pismo wiceminister Krassowskiej o urlopowaniu Ingardena do czasu likwidacji zajmowanej przez niego katedry). 
W tym czasie, pod koniec 1949 roku, Ingarden dostał jeszcze jedną propozycję. Postanowiono, niejako ignorując decyzję o jego przeniesieniu w stan nieczynny, powołać go na opiekuna Katedry Filologii Germańskiej do czasu jej obsadzenia, co stanowiło wybieg formalny. Ingarden został tam przydzielony czasowo. Nie był mocno związany z powierzoną mu katedrą. Figurował tam krótko, jako zastępca, bez żadnej konkretnej nominacji. Dobrze się jednak sprawował na tym stanowisku. Rektor chciał go nawet zatrudnić na stałe w charakterze profesora kontraktowego w Katedrze Filologii Germańskiej, jednak po piśmie z Ministerstwa Oświaty z 31 października 1951 roku zmienił zdanie i odstąpił od tego zamiaru ${ }^{27}$.

Z kolei w piśmie z 22 marca 1951 roku od rektora Uniwersytetu Jagiellońskiego Ingarden otrzymał wiadomość: „Ministerstwo Szkół Wyższych i Nauki, pismem z dnia 14 marca 1951 r. Nr DK.II-3a/443/51, udzieliło Mu płatnego urlopu do końca roku akademickiego 1950/51"28.

Nie było to jednoznaczne, oczywiście, z zakończeniem sprawy w tym momencie. Utrata katedry, jak wiemy, oznaczała dla Ingardena przeniesienie w tzw. stan nieczynny. Posunięcie ze strony Ministerstwa Szkół Wyższych i Nauki okazało się o tyle zręczne, że unieruchamiało Ingardena na całym obszarze uniwersyteckim. Pozostała mu jedynie redakcja Kwartalnika Filozoficznego, a i ta nie miała trwać długo. W 1951 roku, po marcowej naradzie u ministra Adama Rapackiego, zamknięto większość starych, przedwojennych czasopism, w tym także kwartalnik prowadzony przez Ingardena.

Jeszcze pod koniec 1950 roku pojawiła się pewna nadzieja. Sprawę przejścia Ingardena na Katedrę Logiki postanowił podjąć na forum Wydziału Filozoficznego Juliusz Kleiner. Jednak w przypadku fenomenologa stan nieczynności nadal obowiązywał. Rektor i dziekan mieli związane ręce. Decyzję odmowną w tej sprawie Kleiner otrzymał 17 stycznia 1951 roku. Prodziekan Wydziału Humanistycznego zawiadamiał:

W odpowiedzi na pismo Obywatela Profesora donoszę uprzejmie, że na razie sprawa powołania prof. dra Romana Ingardena na Katedrę Logiki nie jest aktualna i nie może być $\mathrm{w}$ formie wniosku postawiona na Radę Wydziału ${ }^{29}$.

27 Zob. „Akta Osobowe - Roman Witold Ingarden (1893-1970)”, „Archiwum Uniwersytetu Jagiellońskiego", S III 246 (Pisma o czasowym zatrudnieniu Ingardena na Katedrze Filologii Germańskiej oraz pismo rektora odstępujące od zatrudnienia Ingardena na tej katedrze na czas nieokreślony).

28 Zob. „Akta Osobowe - Roman Witold Ingarden (1893-1970)”, „Archiwum Uniwersytetu Jagiellońskiego", S III 246 (Pismo rektora Uniwersytetu Jagiellońskiego o płatnym urlopowaniu Ingardena przez Ministerstwo Oświaty).

29 Zob. „Akta Osobowe - Roman Witold Ingarden (1893-1970)”, , Archiwum Uniwersytetu Jagiellońskiego", S III 246 (Pismo prodziekana Wydziału Humanistycznego 
Rok 1951 okazał się dla Ingardena przede wszystkim czasem próby. Filozof był atakowany i poddawany nagonce partyjnej przed agitatorów dobrze zadomowionych na Uniwersytecie Jagiellońskim. Musiał wykazać się nie lada odpornością psychiczną. Pierwsza smutna informacja głosiła konieczność likwidacji zajmowanej przez Ingardena katedry, która przestała istnieć 1 stycznia 1951 roku. Był to ogromny cios, który spadł na filozofa. Spodziewał się on co prawda takiego obrotu sprawy, lecz myślał, że może nastąpi to z końcem roku akademickiego 1950/1951. Skrycie wierzył jeszcze, że dostanie szansę innego zatrudnienia na Uniwersytecie Jagiellońskim, gdzie po wojnie zaangażował się we wszelkie możliwe formy aktywności dydaktycznej oraz naukowej i oddał temu całą swoją energię. Tak się jednak nie stało. Nie potrafił znaleźć sobie miejsca. Zaprzestał także prowadzenia pracy naukowej.

Wówczas też rozhulał się na dobre wewnątrzuczelniany proces oceny Ingardena przez różne komórki partyjne i przypartyjne krakowskiej Alma Mater. 30 lipca 1950 roku filozof został poddany ocenie ze strony Kierownika Oddziału Kadr Zdzisława Łopatki i I Sekretarza Komitetu Uczelnianego PZPR Tadeusza Kościańskiego. Ingardenowi wystawił też osobną opinię Bogdan Kędzierek, I Sekretarz POP PZPR przy Uniwersytecie Jagiellońskim. Pojawiła się też jeszcze jedna opinia: towarzyszy ze Związku Młodzieży Polskiej, a ściślej rzecz ujmując - z Zarządu Uczelnianego przy Uniwersytecie Jagiellońskim w Krakowie. Opinię tę wystawili Kierownik Sekcji Ewaluacji Kadr Marian Czubasiewicz i Przewodniczący Wacław Pituła.

Cóż można było zrobić w tej sytuacji? Nic konkretnego nie przychodziło Ingardenowi w tym momencie do głowy. Nie mógł liczyć na wsparcie kolegów, poza dobrym słowem Dąmbskiej i wsparciem rodziny. Nie zamierzał też dyskutować z marksistami i komunistami, chodzić i prosić o litość. Oczekiwał jednego - szybkiego zwolnienia. I stałoby się to niechybnie, gdyby miało zależeć tylko od środowiskowych władz partyjnych. W Warszawie jednak ktoś doszedł do wniosku, że zwolnienie Ingardena mogło przynieść więcej szkód niż pożytku. Schaff i inni decydenci partyjni wiedzieli, że światowa filozofia wobec tego czynu nie pozostanie bierna. Wstrzymano się więc z wykonaniem "egzekucji”. Jednym z możliwych rozwiązań było zmuszenie Ingardena do przejścia na emeryturę, jak zaproponował rektor Uniwersytetu Jagiellońskiego w liście do ministerstwa z 30 sierpnia 1951 roku:

W związku z upływem z dniem 31 VIII 1951 r. płatnego urlopu Dr Romana Ingardena, profesora zwyczajnego na Wydziale Humanistycznym UJ,

UJ do J. Kleinera o odmowie zatrudnienia Ingardena w Katedrze Logiki Uniwersytetu Jagiellońskiego). 
proszę o wydanie dalszych zarządzeń odnośnie do osoby wymienionego, względnie przeniesienie go na emeryturę ${ }^{30}$.

Rozwiązanie rektora nie podobało się w Warszawie. Minister jednoznacznie wskazał w swoim piśmie z 10 listopada 1951 roku, że obywatela Ingardena Romana należy w dalszym ciągu urlopować w roku akademickim 1951/1952 i wypłacać mu stosowną należność za pracę ${ }^{31}$. W tym czasie fenomenolog dostał z Ministerstwa Oświaty pozwolenie na zajęcie dodatkowe w utworzonej właśnie „Bibliotece Klasyków Filozofii" 32 , w czym widział szansę na rozwój naukowy i zrobienie czegoś dobrego dla filozofii polskiej. Podobnie myśleli inni przedwojenni profesorowie filozofii. W akcję włączyli się, obok Ingardena i Dąmbskiej, Kotarbiński, Gromska, Czeżowski, Tatarkiewicz, Ajdukiewicz i inni. Nie było wówczas łatwo dojść do porozumienia z komunistami, lecz rzecz była warta świeczki.

Wróćmy jednak do Ingardena. Wstrzymane przez Warszawę w 1951 roku jego zwolnienie z Uniwersytetu Jagiellońskiego postanowiono zamienić pod koniec października 1952 roku na mniej surowy wyrok za wrogą postawę wobec marksizmu. Ingarden został służbowo przeniesiony z Uniwersytetu Jagiellońskiego na Uniwersytet Warszawski. W stosownym piśmie z 14 listopada 1952 roku minister Rapacki pisał do niego:

Na podstawie art. 55 ustawy z dnia 15 grudnia 1951 r. o szkolnictwie wyższym i o pracownikach nauki (Dz.U. z 1952 r. Nr 6, poz. 38) przenoszę Obywatela Profesora z urzędu, z dniem 1 listopada 1952 r., z Katedry Logiki na Wydziale Filozoficzno-Społecznym Uniwersytetu Jagiellońskiego w Krakowie do pracy naukowej w Instytucie Filozoficznym na Wydziale Filozoficzno-Społecznym Uniwersytetu Warszawskiego w Warszawie, z zachowaniem tytułu naukowego profesora zwyczajnego. Dotychczasowe zasadnicze uposażenie Obywatela Profesora pozostaje bez zmian. Celem objęcia owych obowiązków winien Obywatel Profesor zgłosić się u Rektora Uniwersytetu Warszawskiego w Warszawie ${ }^{33}$.

30 Zob. "Akta Osobowe - Roman Witold Ingarden (1893-1970)”, „Archiwum Uniwersytetu Jagiellońskiego", S III 246 (Pismo rektora Uniwersytetu Jagiellońskiego do Ministerstwa Szkół Wyższych i Nauki w sprawie Romana Ingardena).

31 Zob. ,Akta Osobowe - Roman Witold Ingarden (1893-1970)”, ,Archiwum Uniwersytetu Jagiellońskiego", S III 246 (Pismo Ministerstwa Oświaty w sprawie Ingardena).

${ }^{32}$ Zob. "Akta Osobowe - Roman Witold Ingarden (1893-1970)”, "Archiwum Uniwersytetu Jagiellońskiego", S III 246 (Pismo Ministerstwa Oświaty zezwalające Ingardenowi na podjęcie pracy dodatkowej poza przyznanym mu urlopem).

33 Zob. "Akta Osobowe - Roman Witold Ingarden (1893-1970)", „Archiwum Uniwersytetu Jagiellońskiego", S III 246 (Pismo ministra Rapackiego przenoszące Ingardena z Uniwersytetu Jagiellońskiego do pracy w Uniwersytecie Warszawskim). 
Ingarden był oszołomiony tą decyzją. Jeszcze większym zaskoczeniem było jednak utworzenie na Uniwersytecie Jagiellońskim w miejsce katedry po Ingardenie Katedry Podstaw Marksizmu. Po tak długim okresie oczekiwania wymiar kary wydawał się jednak łagodny. Co więcej, Ingarden zachował status profesora zwyczajnego i nadal był profesorem nieczynnym. Nie prowadził zajęć, ale zajmował się własnymi sprawami naukowymi. $Z$ racji dobrze wypełnianych obowiązków został też niemal natychmiast urlopowany w Uniwersytecie Warszawskim. Mógł prowadzić działalność translatorską w BKF-ie. Nie stronił też od pracy w Polskim Towarzystwie Filozoficznym. A gdy miał już wszystkiego dosyć, to tłumacząc się względami klimatycznymi, wpływającymi na stan zdrowia, prosił o miesięczny lub dłuższy urlop i wyjeżdżał do Zakopanego w celu podratowania zdrowia.

Lata 1952-1956 to w życiu Ingardena trudny czas podróży między Krakowem a Warszawą. Był to również okres zmasowanych ataków na filozofa. Został on wówczas niespodziewanie ugodzony przez Tadeusza Krońskiego, który jeszcze przed wojną w 1939 roku starał się u niego we Lwowie o asystenturę. $Z$ powodu wojny nic jednak $z$ tego nie wyszło, a po wojnie rozwój intelektualny Krońskiego przebiegał już li tylko $\mathrm{w}$ kierunku marksistowskim. Lepsze stosunki Ingarden zachował z Krońską z racji ich przedwojennych kontaktów, choć i tu nie brakowało sporów na polu przekładów dzieł światowych w BKF-ie. Zawiązał wówczas wraz z Dąmbską swoisty tandem. Wzięli się do prac translatorskich i - jak wiemy - wiele dobrego uczynili dla polskiej filozofii.

Uniwersyteckie wygnanie Ingardena do Warszawy trwało cztery lata. Szansa na jego zakończenie pojawiła się w 1956 roku. Wówczas to pomoc przyszła ze strony Wydziału Filozoficzno-Historycznego Uniwersytetu Jagiellońskiego. Tamtejsza Rada Wydziału poprosiła rektora tejże uczelni, aby ten wystąpił do Ministerstwa Szkolnictwa Wyższego z petycją o przywrócenie Ingardena na zabraną mu Katedrę Filozofii. 14 grudnia 1956 roku w imieniu Rady Wydziału Filozoficzno-Historycznego Uniwersytetu Jagiellońskiego stosowne pismo do Ministerstwa Oświaty skierował dziekan, prof. Henryk Barycz. Decyzja Rady Wydziału Filozoficzno-Historycznego dla rektora, a tym bardziej dla władz ministerialnych, okazała się wielkim zaskoczeniem. Ówczesny rektor Uniwersytetu Jagiellońskiego, prof. dr Zygmunt Grodziński, przed przekazaniem sprawy Ingardena do Senatu Uniwersyteckiego nie wydał swojej opinii w obawie przed narażeniem się władzom partyjnym. Jak zapisał w piśmie z 17 grudnia 1956 roku do Senatu Uniwersytetu Jagiellońskiego:

Odstępuje się od wydania opinii stosownie do art. 11 ustawy o Szkolnictwie Wyższym (Dz.U.R.P., Nr 45/46 poz. 295) w sprawie powrotu prof. 
dra Romana Ingardena do czynnej pracy jako profesora zwyczajnego przy Katedrze Filozofii Ogólnej ${ }^{34}$.

Długo też zwlekano w Ministerstwie Szkolnictwa Wyższego. Dopiero po licznych konsultacjach zdecydowano, że lepiej będzie dla wszystkich, jak Ingarden wróci na krakowską uczelnię. Zresztą w Warszawie Ingardena nie lubiano. Choć rzadko tam bywał, dał się wielokrotnie we znaki zarówno władzom uczelnianym, jak i kolegom po fachu. Mimo iż w tym okresie głównie milczał, to i tak wszyscy mieli dość filozofa o trudnym charakterze, oportunistycznie nastawionego do panującej wówczas zatęchłej atmosfery. Sam Ingarden miał także nadzieję, że odłączy się wreszcie od warszawskiego bastionu marksizmu i nie będzie musiał widywać się, nawet rzadko, ze swoimi rzekomymi kolegami ani znosić złośliwych impertynencji marksistów. Decyzja z Ministerstwa Szkolnictwa Wyższego dotarła do Ingardena 13 lutego 1957 roku. Był to chyba jeden ze szczęśliwszych dni w jego życiu. Znana mu już dość dobrze minister Krassowska zdecydowała się wówczas na przekazanie do rąk własnych Ingardena pisma o następującej treści:

Na podstawie art. 62 ustawy z dnia 15 grudnia 1951 r. o szkolnictwie wyższym i o pracownikach nauki w brzmieniu obwieszczenia $\mathrm{z}$ dnia 10 października 1956 r. (Dz.U. nr 45, poz. 205) przenoszę Obywatela Profesora z urzędu z dniem 1 lutego 1957 r. z Uniwersytetu Warszawskiego w Warszawie na Katedrę Logiki na Wydziale Filozoficzno-Historycznym Uniwersytetu Jagiellońskiego w Krakowie.

Dotychczasowe zasadnicze uposażenie Obywatela Profesora pozostaje bez zmiany.

Celem objęcia nowych obowiązków zechce Obywatel Profesor zgłosić się u Obywatela Rektora Uniwersytetu Jagiellońskiego w Krakowie ${ }^{35}$.

Wyniosły ton pisma minister Krassowskiej nie zdziwił Ingardena. Czuł w tym momencie wielką radość z powrotu na Uniwersytet Jagielloński i nie było dla niego ważne, na jaką katedrę wracał, lecz że wracał w ogóle. Nie przeszkadzało mu, że będzie musiał pracować w Katedrze Logiki. Lepszy rydz niż nic - musiał pomyśleć sobie Ingarden, po czym $\mathrm{z}$ wielkim zapałem zabrał się do pracy.

34 Zob. "Akta Osobowe - Roman Witold Ingarden (1893-1970)”, „Archiwum Uniwersytetu Jagiellońskiego", S III 246 (Pismo rektora Uniwersytetu Jagiellońskiego w sprawie odstąpienia od wydania opinii o zatrudnieniu Ingardena w Uniwersytecie Jagiellońskim).

35 Zob. „Akta Osobowe - Roman Witold Ingarden (1893-1970)", „Archiwum Uniwersytetu Jagiellońskiego", S III 246 (Pismo minister Krassowskiej o przywróceniu Ingardena do pracy na Uniwersytecie Jagiellońskim i zatrudnieniu go w Katedrze Logiki). 
Semestr letni roku akademickiego 1956/1957 nie był dla Ingardena szczytem marzeń. Filozof znalazł się co prawda ponownie na Uniwersytecie Jagiellońskim, lecz związane z jego powrotem reakcje zarówno rektora, jak i komórek partyjnych nie były zbyt entuzjastyczne. Nikt wówczas nie potrafił przyznać się do popełnionych w przeszłości błędów i powiedzieć: „Przepraszam”. Z dużym zainteresowaniem przyglądano się temu nagłemu powrotowi. Co więcej, w podjętej przez Ingardena pracy przysparzano mu kolejnych trudności. Filozof wiedział, że oczekiwane przez niego zmiany wcześniej czy później i tak będą musiały nastąpić.

Jesienią 1957 roku, tuż przed nowym rokiem akademickim, doszło do jeszcze jednego ważnego wydarzenia. Dziekan Wydziału Filozoficzno-Historycznego spełnił wówczas daną Ingardenowi obietnicę. Chodziło o przywrócenie filozofowi utraconej katedry wraz z zakładem. W stosownym piśmie do Rektoratu Uniwersytetu Jagiellońskiego zwracał się z następującą prośbą:

Dziekanat Wydziału Filozof.-Historycznego UJ w oparciu o uchwałe Rady Wydziału Filozoficzno-Historycznego UJ z dnia 11 XII 56 r. prosi o powierzenie prof. dr Romanowi Ingardenowi kierownictwa Katedry Filozofii wraz z Zakładem ${ }^{36}$.

Pismo to miał oczywiście zaopiniować rektor Uniwersytetu Jagiellońskiego, prof. Grodziński, i wysłać je do Senatu Akademickiego. Jednak i tym razem odstąpił od tego zamiaru i nie zaopiniował powołania Ingardena na utraconą przez niego katedrę wraz z zakładem. Zwrócił się ponownie ze stosownym pismem 28 września 1957 roku do Senatu Uniwersytetu Jagiellońskiego. Pisał:

Odstępuję w myśl art. 11, p. 2 ustawy z dnia 15 XIII 1951 r. o szkolnictwie wyższym i o pracownikach nauki - celem wyrażenia opinii w sprawie powierzenia prof. dr Romanowi Ingardenowi kierownictwa Katedry Filozofii wraz z Zakładem ${ }^{37}$.

Pismo nie zdziwiło ani dziekana Barycza, ani Ingardena. Sprawa przeszła bowiem przez Senat Uniwersytetu Jagiellońskiego, a rektor

36 Zob. „Akta Osobowe - Roman Witold Ingarden (1893-1970)”, „Archiwum Uniwersytetu Jagiellońskiego", S III 246 (Pismo dziekana Wydziału HistorycznoFilozoficznego o przywróceniu Ingardena na zajmowaną przez niego wcześniej II Katedrę Filozofii wraz z Zakładem).

37 Zob. "Akta Osobowe - Roman Witold Ingarden (1893-1970)”, „Archiwum Uniwersytetu Jagiellońskiego", S III 246 (Pismo rektora Uniwersytetu Jagiellońskiego o odstąpieniu od wydania opinii w sprawie zatrudnienia Ingardena na II Katedrze Filozofii wraz z Zakładem). 
Grodziński nie miał wyjścia i musiał powołać Ingardena na Katedrę Filozofii wraz z Zakładem. Stało się to 29 października 1957 roku. W stosownym piśmie czytamy:

W związku z utworzeniem Katedry Filozofii, dokonanym na wniosek Rady Wydziału Filozoficzno-Historycznego i Senatu UJ, zarządzeniem Ministra Szkolnictwa Wyższego z dnia 30 VII 57, ogłoszonym w Dzienniku Urzędowym MSW i CKK nr 9/57 i zgodnie z jednogłośną uchwałą Rady Wydziału Filozoficzno-Historycznego i Senatu UJ, mianuję Pana Profesora od dnia 1 września 1957 r. kierownikiem Katedry Filozofii, przydzielając równocześnie do wymienionej katedry zastępcę profesora, kandydata nauk Zdzisława Augustynka, adiunktów: mgra Zbigniewa Majewskiego i dra Jana Leszczyńskiego, starszych asystentów: mgra Andrzeja Półtawskiego i mgra Michała Hempolińskiego oraz asystenta mgra Stanisława Surmęe

\section{Bibliografia}

„Akta Osobowe - Roman Witold Ingarden (1893-1970)”, ,Archiwum Uniwersytetu Jagiellońskiego", S III 246 (Legitymacja tymczasowa Nr 380 Romana Ingardena, wydana przez prorektora Uniwersytetu Jagiellońskiego Tadeusza Dziurzyńskiego 1 lutego 1945 r.).

"Akta Osobowe - Roman Witold Ingarden (1893-1970)”, ,Archiwum Uniwersytetu Jagiellońskiego", S III 246 (Odpis z 12 kwietnia 1946 r. umowy o pracę zawartej między rektorem Uniwersytetu Jagiellońskiego Tadeuszem Lehrem-Spławińskim a Romanem Witoldem Ingardenem w Krakowie 1 grudnia 1945 r.).

"Akta Osobowe - Roman Witold Ingarden (1893-1970)”, „Archiwum Uniwersytetu Jagiellońskiego", S III 246 (Niepodpisana przez rektora umowa o pracę między rektorem Uniwersytetu Jagiellońskiego a Romanem Witoldem Ingardenem z 15 lipca 1946 r.).

„Akta Osobowe - Roman Witold Ingarden (1893-1970)”, „Archiwum Uniwersytetu Jagiellońskiego", S III 246 (List Ingardena do dziekana Wydziału Humanistycznego o warunkach zatrudnienia).

"Akta Osobowe - Roman Witold Ingarden (1893-1970)", „Archiwum Uniwersytetu Jagiellońskiego", S III 246 (Pismo Rady Wydziału Humanistycznego o przyjęciu Ingardena w poczet swoich członków).

„Akta Osobowe - Roman Witold Ingarden (1893-1970)”, „Archiwum Uniwersytetu Jagiellońskiego", S III 246 (Nominacja Ingardena na II Katedrę Filozofii w Uniwersytecie Jagiellońskim).

38 Zob. "Akta Osobowe - Roman Witold Ingarden (1893-1970)", „Archiwum Uniwersytetu Jagiellońskiego", S III 246 (Pismo rektora Uniwersytetu Jagiellońskiego powołujące Ingardena na zajmowaną przez niego wcześniej II Katedrę Filozofii wraz z Zakładem). 
"Akta Osobowe - Roman Witold Ingarden (1893-1970)”, ,Archiwum Uniwersytetu Jagiellońskiego", S III 246 (Deklaracja osobowa Ingardena o sobie i rodzinie).

„Akta Osobowe - Roman Witold Ingarden (1893-1970)”, ,Archiwum Uniwersytetu Jagiellońskiego", S III 246 (Pismo wspierające Rady Wydziału i zatwierdzenie nominacji Ingardena z Ministerstwa Oświaty).

„Akta Osobowe - Roman Witold Ingarden (1893-1970)”, „Archiwum Uniwersytetu Jagiellońskiego", S III 246 (Dokumenty dotyczą okresu pracy w Lublinie, Warszawie, Toruniu i Lwowie w okresie przedwojennym).

"Akta Osobowe - Roman Witold Ingarden (1893-1970)", "Archiwum Uniwersytetu Jagiellońskiego", S III 246 (Ingarden z trudem zyskał te dokumenty i z potwierdzeniem notarialnym złożył ostatecznie w UJ).

„Akta Osobowe - Roman Witold Ingarden (1893-1970)”, ,Archiwum Uniwersytetu Jagiellońskiego", S III 246 (Rektorat uznał, że Ingarden jest zbyt opieszały w gromadzeniu i przedłożeniu stosownych dokumentów i w 1947 wysłał do niego stosowne ponaglenie).

„Akta Osobowe - Roman Witold Ingarden (1893-1970)", ,Archiwum Uniwersytetu Jagiellońskiego", S III 246 (Nominacja Ingardena na profesurę zwyczajną).

"Akta Osobowe - Roman Witold Ingarden (1893-1970)”, ,Archiwum Uniwersytetu Jagiellońskiego", S III 246 (Pismo służbowe Ingardena do dziekana Wydziału Matematyczno-Przyrodniczego Uniwersytetu Jagiellońskiego w sprawie rezygnacji z zajęć i funkcji służbowych).

„Akta Osobowe - Roman Witold Ingarden (1893-1970)”, ,Archiwum Uniwersytetu Jagiellońskiego", S III 246 (Pismo dziekana Wydziału Matematyczno-Przyrodniczego Uniwersytetu Jagiellońskiego do prof. Heinricha w sprawie objęcia przez niego stanowiska zwolnionego po Ingardenie).

"Akta Osobowe - Roman Witold Ingarden (1893-1970)", "Archiwum Uniwersytetu Jagiellońskiego", S III 246 (Postanowienie rektora Uniwersytetu Jagiellońskiego o urlopowaniu Ingardena do czasu likwidacji zajmowanej przez niego katedry).

„Akta Osobowe - Roman Witold Ingarden (1893-1970)”, „Archiwum Uniwersytetu Jagiellońskiego", S III 246 (Pismo wiceminister Krassowskiej o urlopowaniu Ingardena do czasu likwidacji zajmowanej przez niego katedry).

„Akta Osobowe - Roman Witold Ingarden (1893-1970)", „Archiwum Uniwersytetu Jagiellońskiego", S III 246 (Pisma o czasowym zatrudnieniu Ingardena na Katedrze Filologii Germańskiej oraz pismo rektora odstępujące od zatrudnienia Ingardena na tej katedrze na czas nieokreślony). "Akta Osobowe - Roman Witold Ingarden (1893-1970)", ,Archiwum Uniwersytetu Jagiellońskiego", S III 246 (Pismo rektora Uniwersytetu Jagiellońskiego o płatnym urlopowaniu Ingardena przez Ministerstwo Oświaty).

"Akta Osobowe - Roman Witold Ingarden (1893-1970)", „Archiwum Uniwersytetu Jagiellońskiego", S III 246 (Pismo prodziekana Wydziału Hu- 
manistycznego UJ do J. Kleinera o odmowie zatrudnienia Ingardena w Katedrze Logiki Uniwersytetu Jagiellońskiego).

„Akta Osobowe - Roman Witold Ingarden (1893-1970)”, "Archiwum Uniwersytetu Jagiellońskiego", S III 246 (Pismo rektora Uniwersytetu Jagiellońskiego do Ministerstwa Szkół Wyższych i Nauki w sprawie Romana Ingardena).

„Akta Osobowe - Roman Witold Ingarden (1893-1970)”, „Archiwum Uniwersytetu Jagiellońskiego", S III 246 (Pismo Ministerstwa Oświaty w sprawie Ingardena).

„Akta Osobowe - Roman Witold Ingarden (1893-1970)”, „Archiwum Uniwersytetu Jagiellońskiego", S III 246 (Pismo Ministerstwa Oświaty zezwalające Ingardenowi na podjęcie pracy dodatkowej poza przyznanym mu urlopem).

„Akta Osobowe - Roman Witold Ingarden (1893-1970)”, „Archiwum Uniwersytetu Jagiellońskiego", S III 246 (Pismo ministra Rapackiego przenoszące Ingardena z Uniwersytetu Jagiellońskiego do pracy w Uniwersytecie Warszawskim).

"Akta Osobowe - Roman Witold Ingarden (1893-1970)", „Archiwum Uniwersytetu Jagiellońskiego", S III 246 (Pismo rektora Uniwersytetu Jagiellońskiego w sprawie odstąpienia od wydania opinii o zatrudnieniu Ingardena w Uniwersytecie Jagiellońskim).

„Akta Osobowe - Roman Witold Ingarden (1893-1970)”, ,Archiwum Uniwersytetu Jagiellońskiego", S III 246 (Pismo minister Krassowskiej o przywróceniu Ingardena do pracy na Uniwersytecie Jagiellońskim i zatrudnieniu go w Katedrze Logiki).

„Akta Osobowe - Roman Witold Ingarden (1893-1970)", „Archiwum Uniwersytetu Jagiellońskiego", S III 246 (Pismo minister Krassowskiej o przywróceniu Ingardena do pracy na Uniwersytecie Jagiellońskim i zatrudnieniu go w Katedrze Logiki).

„Akta Osobowe - Roman Witold Ingarden (1893-1970)”, "Archiwum Uniwersytetu Jagiellońskiego", S III 246 (Pismo dziekana Wydziału Historyczno-Filozoficznego o przywróceniu Ingardena na zajmowaną przez niego wcześniej II Katedrę Filozofii wraz z Zakładem).

„Akta Osobowe - Roman Witold Ingarden (1893-1970)", „Archiwum Uniwersytetu Jagiellońskiego", S III 246 (Pismo rektora Uniwersytetu Jagiellońskiego o odstąpieniu od wydania opinii w sprawie zatrudnienia Ingardena na II Katedrze Filozofii wraz z Zakładem).

„Akta Osobowe - Roman Witold Ingarden (1893-1970)", „Archiwum Uniwersytetu Jagiellońskiego", S III 246 (Pismo rektora Uniwersytetu Jagiellońskiego powołujące Ingardena na zajmowaną przez niego wcześniej II Katedrę Filozofii wraz z Zakładem).

"Akta Prof. Roman Ingarden”, „Archiwum Uniwersytetu Jagiellońskiego", WHm 41 (Wypis z posiedzenia Rady Wydziału Filozoficznego UJ w dniu 15 maja 1945).

"Akta Prof. Roman Ingarden", „Archiwum Uniwersytetu Jagiellońskiego", WHm 41 (List Ingardena do dziekana Wydziału Humanistycznego Uni- 
wersytetu Jagiellońskiego w sprawie pracy w nowym roku akademickim).

Dyplom doktorski (kopia) Romana Witolda Ingardena, potwierdzona przez Władysława Podlachę, dziekana Wydziału Humanistycznego UJK 6 marca 1931 r., Archiwum Lwowskiego Narodowego Uniwersytetu imienia Iwana Franki, оп. 1, ед. хр. 73: Личное дело профессора немецькой литературы Ингардена Романа Романовича, k. 10r.

Kuliniak Radosław, Pandura Mariusz, Ratajczak Łukasz. 2019. Filozofia po ciemnej stronie mocy. Krucjaty marksistów i komunistów polskich przeciwko Lwowskiej Szkole Filozoficznej Kazimierza Twardowskiego. Część II: Problem reformy szkolnictwa wyższego w świetle partyjnej ofensywy ideologicznej. Kęty: Wydawnictwo Marek Derewiecki.

Protokół ze 173 posiedzenia Wydziału Polskiego Towarzystwa Filozoficznego we Lwowie, „Księga protokołów Polskiego Towarzystwa Filozoficznego we Lwowie od dn. 12 lutego 1930 roku", zawiera: Protokoły od 170 Posiedzenia Wydziału od dn. 9. V 1930 roku do Protokołu 198 Posiedzenia Wydziału z dn. 30 . VI 1939 roku, w: Archiwum Ośrodka Lwowskiego w zbiorach Połączonych Bibliotek WFiS UW, IFiS PAN i PTF. Przyczynek do inwentarza, opracował Łukasz Ratajczak, Rkp. 2 PAN.

„Roman Ingarden”, „Archiwum Uniwersytetu Jagiellońskiego”, WMP 78 (List dziekana Wydziału Matematyczno-Przyrodniczego do Ingardena z podziękowaniami za współpracę).

„Roman Ingarden”, „Archiwum Uniwersytetu Jagiellońskiego”, WMP 78 (List Ingardena do dziekana Wydziału Matematyczno-Przyrodniczego Uniwersytetu Jagiellońskiego w sprawie przydziału zajęć z filozofii na tym wydziale). List został błędnie datowany „5 VI 1950” (właściwa data: 5 lipca 1950 r.).

„Ku uczczeniu pamięci Kazimierza Twardowskiego”. 1938. Ruch Filozoficzny 1-3, XIV: 40-45.

Studia Philosophica. Commentarii Societatis Philosophicae Polonorum. 1939-1946, vol. 3, wyd. 1948: „In memoriam philosophorum Polonorum qui inde ab A. D. MCMXXXVIII mortui sunt".

„W pierwszą rocznicę zgonu Kazimierza Twardowskiego". 1939. Ruch Filozoficzny 1/2, 15: 5-8.

„Wstęp" do Korespondencji Romana Witolda Ingardena. Z dziejów „Studia Philosophica. Commentarii Societatis Philosophicae Polonorum", listy przeczytali, przepisali oraz wstępem poprzedzili Radosław Kuliniak, Dorota Leszczyna, Mariusz Pandura, Łukasz Ratajczak, Kęty, 2018, 7-165.

\section{Streszczenie}

Niniejszy artykuł ukazuje kwestie awansu naukowego i zatrudnienia Romana Witolda Ingardena. Był to okres niezwykle ciężki dla filozofa. Został on w tym czasie poddany wielu represjom ze strony zarówno władz uniwersyteckich, jak i kolektywu partyjnego. Wiązało się to z prowadzoną zaraz po II wojnie 
światowej na polskich uniwersytetach walką ideologiczna, skierowaną przede wszystkim przeciwko uczniom z filozoficznej szkoły lwowskiej Kazimierza Twardowskiego. Ingarden stał się jedną z ofiar tej nagonki ze strony komunistów i marksistów. Skutkowało to odsunięciem go od zajęć dydaktycznych oraz karnym przeniesieniem z Uniwersytetu Jagiellońskiego na Uniwersytet Warszawski. W tym czasie filozof wykazał się niebywałą odwagą i nie uległ komunistycznemu reżimowi.

Słowa kluczowe: Roman Witold Ingarden, komunizm, marksizm, inwigilacja, represje.

\section{Summary}

This article presents the issues of the scientific promotion and employment of Roman Witold Ingarden. It was an extremely difficult period of the philosopher's life. At that time, he was subject to many repressions by the university authorities and the party collective. This was connected with the ideological struggle students at Polish universities, and particularly those from the Lviv Philosophical School of Kazimierz Twardowski were locked in after World War II. Ingarden became one of the victims of the communist and Marxist repressions. This resulted in his dismissal from teaching and a transfer from the Jagiellonian University to the University of Warsaw. At that time, the philosopher showed incredible courage and did not succumb to the communist regime.

Keywords: Roman Witold Ingarden, communism, Marxism, surveillance, repression. 